\title{
As cartas do padre Antônio Vieira no Maranhão: apontamentos sobre a teologia-política das missões na retórica epistolar
}

\author{
Fernando Munhós
}

\begin{abstract}
RESUMO: O presente ensaio tem por objetivo apresentar algumas particularidades da retórica das cartas escritas pelo padre Antônio Vieira entre 1653 e 1661, período em que atuou como missionário no Estado do Maranhão e Grão-Pará. Pretende, assim, apontar como os procedimentos e técnicas da representação nos textos são determinantes para a viabilidade das ações do jesuíta na conversão dos índios e na administração dos aldeamentos, ao articular para destinatários interessados os conceitos centrais da política católica do Estado português do século XVII. Com isso, almeja-se propor uma perspectiva histórica sobre a relação de Vieira com a presença, na região, do trabalho cativo dos índios.
\end{abstract}

PALAVRAS-CHAVE: Companhia de Jesus; Antônio Vieira; retórica; escravidão; saberes.

\footnotetext{
ABSTRACT: This paper aims to present some of the rhetoric particularities of letters written by Father Antônio Vieira between 1653 and 1661, period during which he served as a missionary in the State of Maranhão and Grão-Pará. Thus it seeks to point out how the procedures and techniques of representation are crucial to the viability of Jesuit actions for Indians' conversion and administration of the settlements by the coordination with the interested consignees of the main concepts concerned to the Catholic policy of the Portuguese State in the $17^{\text {th }}$ century. Thus, the text aims to offer a historical perspective on Vieira's relationship with the presence of the bonded labor of the Indians in the region.
}

KEYWORDS: Society of Jesus; Antônio Vieira; rhetoric; slavery; knowledge. 
[...] porque das relações, que agora se imprimem, se compõem depois as histórias, e quem mais e melhor escreveu de si foi o que melhor parte teve nos anais da fama. ${ }^{1}$

Sabemos com Michel Foucault que o saber no século xvi não distingue o que se vê e o que se lê. $\mathrm{O}$ olhar e a linguagem se entrelaçariam, ${ }^{2}$ diz o filósofo, pois a experiência da linguagem pertenceria à própria ordem da natureza. Conhecer as coisas que a constituem seria descobrir o sistema de semelhanças que as aproxima. ${ }^{3}$ Nesse sentido, a linguagem não seria um instrumento que dá forma às matérias do discurso, mas matéria ela mesma que coloca diante dos olhos os graus de semelhança e desconveniência entre as coisas. ${ }^{4}$ Os saberes, no plural, estão necessariamente vinculados às diversas práticas que o homem, em comunidade, articula na ação político-teológica e nos procedimentos retórico-poéticos, pelos quais a sua eficácia está diretamente relacionada ao sentido das coisas, estabelecido por tais aproximações. Mais recentemente, Roger Chartier observou que os procedimentos relativos à materialidade dos textos produzidos entre os séculos XVI e XVIII - como, por exemplo, publicar um livro, ler um poema ou enviar uma carta - não estão, em definitivo, separados das operações de sentido calcadas nas trocas e apropriações desses saberes, muitas vezes difusos, que determinam sobretudo os modos de persuadir. ${ }^{5}$ Fio-me ao caso da carta, de particular interesse aqui, como exemplo: os saberes que circulam pelo Ocidente desde pelo menos o mundo greco-romano e que dizem ao emissor o que é mais persuasivo na retórica epistolar quanto às matérias da invenção e da disposição vão determinar os seus atos de escrita e de leitura.

Não somente nos textos podemos localizar os diversos usos dos saberes, legíveis, para nós, na proporção em que buscamos conhecer seus modos de circulação e apropriação para fins contingentes. Qualquer categoria de representação - e em se tratando do Ocidente no século XVII não existe prática interpessoal que não seja mediada por uma representação - carrega em si seus preceitos pelos quais fica garantida a

1. Carta de Pe. Antônio Vieira a d. Rodrigo de Meneses, 10 ago. 1665.

2. Foucault, Michel. Les mots et les choses. França: Gallimard, 1966, p. 54.

3. Idem, p. 56.

4. As coisas, segundo Foucault, possuem graus de semelhança estabelecidos pela conveniência, emulação, analogia e simpatia. Cf. FoucAult, Michel. Op. cit., p. 32-59.

5. Cf. Chartier, Roger. “O mundo como representação". Estudos Avançados, São Paulo, vol. 5, n. 11, pp. 173-91, abr. 1991. 
eficácia persuasiva, como nas artes pictóricas e plásticas, nos elementos arquitetônicos, na cartografia etc. Na medida em que buscamos estabelecer, quase como arqueólogos, essa conexão entre o dispositivo - uma carta, um quadro, um mapa ou uma pilastra, hoje presentes como uma ruína de um tempo passado - e os saberes lá presentes que determinaram seus atributos e as aproximações ali contidas, conseguiremos ir ainda mais longe. Será possível, a partir da análise dessas ruínas, estabelecer hipóteses sobre a ação política local dos homens inseridos em determinados contextos que interessam, em sua legibilidade, ao pensamento histórico. De pronto, é possível afirmar: as ações políticas de um personagem histórico como o padre jesuíta Antônio Vieira são também, em alguma medida, determinadas pela circularidade de saberes, até o século XVII, presentes nos diversos territórios europeus por onde ele passou em sua vida, assim como no Estado do Brasil e no Estado do Maranhão e Grão-Pará. Estabelecer algumas dessas conexões e os suportes por onde elas se mantinham é o intento inicial deste texto.

Dito de outra forma, os modos de lidar com a circularidade e apropriação dos saberes incidem diretamente no grau de eficácia persuasiva das representações e das práticas políticas inseridas em determinados contextos teológico-culturais, como o processo de conversão do índio e sua inserção no corpo político do Império português. Data de janeiro de 1653 a primeira carta de que se tem notícia de Antônio Vieira recém-chegado ao Maranhão, endereçada ao primogênito do rei d. João IV, o príncipe d. Teodósio de Bragança. ${ }^{6}$ Após anos de atuação nas cortes de Roma, Paris e Haia, negociando em nome da soberania do reino português diante da separação das cortes portuguesa e espanhola, e da presença holandesa em território americano, Vieira aporta no Estado do Maranhão e Grão-Pará.

Já era forte, porém, a hostilidade dos moradores locais à presença de padres na região. João Lúcio de Azevedo conta que se levantava contenda contra qualquer missionário que para lá se deslocasse ao menos desde 1610, data da presença dos capuchos franceses na região, passando na década seguinte aos franciscanos, o que na década de 1650 será o conflito voltado majoritariamente contra padres inacianos. ${ }^{7}$ É nesse quadro

6. Seria esta missiva a última, porém, das escritas pelo jesuíta ao estimado sucessor do trono português, pois naquele mesmo ano viria a notícia de sua morte, aos dezenove anos, por consequência de uma saúde frágil. Cf. "Introdução" de vieira, Pe. Antônio. Obra completa. Tomo I: epistolografia, volume II: cartas da missão; cartas da prisão. Dir. José Eduardo franco, Pedro Calafate. São Paulo: Loyola, 2014.

7. Estes, diz Azevedo, chegam pela primeira vez ao Maranhão em 1610, quando encontram um ambiente 
que Vieira encontra o Maranhão, depois de passar rapidamente por Cabo Verde, saído de Lisboa, deixando para trás algum desentendimento com o rei que, segundo o que narra Azevedo, se encontrava descontente com a proximidade exagerada do padre ao príncipe d. Teodósio. ${ }^{8}$ Permanecerá nesse interior da América portuguesa por mais de oito anos, nos quais não trata de outro assunto central que não seja a defesa do índio enquanto súdito convertido do reino português.

É indispensável salientar a necessidade de se pensar esse período de atuação de Vieira nos assuntos das missões, para além do que comumente se indaga a respeito de seus posicionamentos, interrogação evidenciada no cotejo entre os diversos textos que aparentam ser de sua autoria. De um lado, vemos a afirmativa de que o jesuíta se contradiz por apoiar a instituição da escravidão como útil aos poderes vigentes. Essa tese destoaria de uma postura de hipotética defesa humanitária universal dos índios, presente em sermões como o da Primeira Dominga da Quaresma, pregado já em março de 1653 em São Luís, leitura que teria ganhado fôlego no sentido de contrapor uma historiografia engajada em reconstituir uma imagem da Companhia de Jesus e particularmente de Nóbrega, Anchieta e Vieira, entre outros, para além de um papel nocivo associado à Ordem. Assim, diante de uma leitura que, desde Simão de Vasconcelos, passando por Serafim Leite e o próprio João Lúcio de Azevedo, aponta para, no máximo, um suposto conformismo descontente de Vieira em admitir a necessidade da escravidão, é possível supor a presença de estudos mais recentes que venham a assinalar tais contradições. Porém, é um tanto arriscado aceitar que a verdade esteja presente no extremo oposto dessa lógica: que Vieira seria, tão somente, o representante da ação puramente cínica dos inacianos, fazendo todos os usos da escravidão de africanos e índios para o próprio benefício de amealhar fortuna e de se associar aos poderes locais.

De outro lado, parece impossível sustentar que os textos de Vieira, em suas diferenças de gênero, ou estilo, revelariam uma pretensa autonomia dos objetivos do padre jesuíta no Estado do Maranhão, ou dos propósitos da Companhia diante de Portugal e da Igreja de Roma, fossem eles para defender a liberdade do índio ou a utilização do trabalho cativo. De um modo ou de outro, o padre não estava - nem poderia estar agindo ao largo do que se cria o futuro do reino e da fé católica. O catolicismo, com suas

hostil à presença dos padres. Depois, em 1636, liderados pelo pe. Luís Figueira, chegam ao Pará. Cf. AZEvEDo, João Lúcio de. História de Antônio Vieira. Portugal, Lisboa: Livraria Clássica Editora, 1931, tomo I, pp. 209-12. 8. Idem, tomo I, pp. 195-8. 
bases escolásticas, não era, para os membros do corpo político do reino português, muito menos para o mais combativo padre da Companhia de Jesus no século xvıI, mera e tão somente ideologia. Possuía, em sua transcendência, a Verdade. Por mais que, hoje, possamos observar Vieira como um grande homem de seu tempo, articulando poderes, ações, em interlocução com personagens centrais da política imperial portuguesa em nome de grandes objetivos, parece difícil exigir, a partir dos papéis que ele deixou, que possuísse uma tal visão totalizante das coisas a ponto de alcançar um grau qualquer de alteridade quanto à presença do ameríndio exposto nos sertões dos domínios lusos. A própria concepção de liberdade, em Vieira, não pode ser objeto de olhares ingênuos por parte dos historiadores que queiram compor uma narrativa sensata sobre as ações do jesuíta.

A presença de Antônio Vieira no Maranhão, tratando das questões da conversão dos índios nos aldeamentos presentes na região, instrumentaliza um conjunto de saberes e doutrinas caras ao catolicismo contrarreformado. Na prática diária da conversão e no texto da carta - enviada para o rei, para a rainha, para o príncipe, para os amigos da corte, para o superior da Ordem ou mesmo para o chefe índio Guaquaíba -, essa instrumentalização traz à tona uma síntese particular das doutrinas, que até aquele presente contexto vinham sendo lidas e pregadas por teólogos portugueses e espanhóis. Estes, desde a chegada dos europeus ao Novo Mundo, estavam constantemente preocupados com os procedimentos de conversão e inserção dos índios nos domínios locais das monarquias.

No século XVII os procedimentos não são distintos dos do século anterior. Vieira escreve a d. Teodósio, em carta de 1653, assim de sua chegada: "Sua Majestade e Vossa Alteza são senhores desta seara, e estão em seu lugar, a cujos reais pés prostrados o pedimos a toda a ânsia." ${ }^{\circ}$ O pedido em questão se refere ao desejo do jesuíta de que o rei d. João IV enviasse, o quanto antes, recursos para viabilizar os planos da Companhia de Jesus na região do Maranhão e Grão-Pará. Esses recursos consistiam principalmente no maior número possível de missionários, "mestres de fé a ensinar e reduzir a Cristo estas gentilidades". E conclui o jesuíta, no último papel escrito ao estimado sucessor do trono português, antes de sua morte: "e persuada-se Vossa Alteza, meu Príncipe, que lhe hão de prestar mais a Vossa Alteza, para a defensão e estabilidade do reino, os exércitos de almas que cá se reduzirem, que os de soldados que lá se alistarem".10 Vieira vê, nas gentilidades presentes nos limites territoriais dos domínios da Coroa, a potência

\footnotetext{
9. Vieira, Pe. Antônio. Obra completa, cit., carta 62, p. 76.

10. Ibidem.
} 
para o engrandecimento do poder do rei português. Ter os índios como súditos do rei católico é, ao mesmo tempo, salvá-los da barbaridade de uma vida sem a fé em Deus e aumentar os poderes do império português, confirmando seus domínios na América. Aumenta-se o corpo trazendo, cada vez em maior número, novos membros a integrar suas partes, mesmo que sejam estas das mais inferiores.

Encontramos nos sermões em favor dos índios, ou na Relação da missão da serra de Ibiapaba, uma síntese pragmática da posição da Companhia de Jesus em relação às doutrinas da Igreja de Roma pós Concílio de Trento. A própria criação da Ordem dos inacianos vem da situação de restruturação do catolicismo diante das novas heresias no século XVI. Lendo sobretudo as teses de Francisco Suárez, mas também de teólogos como o professor de Salamanca, Francisco de Vitória, além das experiências de Manuel da Nóbrega com os modelos de conversão nas regiões da Bahia e de São Vicente um século antes, Vieira situava-se impondo, como a Verdade da fé em Cristo, a liberdade como submissão ao rei católico. Para isso, afirma o tempo todo em suas cartas ser necessário tanto aos padres que cuidam dos aldeamentos, quanto aos que vão para o sertão reduzir as tribos, a autonomia de ação. A conquista e a manutenção da autonomia dos padres inacianos diante dos poderes locais no Maranhão e Grão-Pará são os principais objetivos pelos quais Vieira despende seus esforços nos anos em que se envolve com as missões.

Novamente é importante afirmar que essa postura de Vieira não é fruto de um olhar autônomo sobre a realidade da região, como se o padre possuísse uma autossuficiência intelectual, nos moldes do sonho do homem romântico, somada à alteridade sobre a condição do índio americano. Não se trata de uma resolução alcançada por um olhar antropológico. Vieira afirma constantemente, durante esse período, a necessidade de se garantir a autonomia da ação dos jesuítas presentes no Maranhão, primeiramente porque tal postura segue as diretrizes da Companhia de Jesus, que determina a subordinação dos padres à estrutura hierárquica da Ordem, relatando com frequência aos superiores os feitos e necessidades locais. Não parece ser preocupação primeira dos padres inacianos prestar contas das suas ações aos membros locais da administração política do reino, exceto àqueles que condizem, nos ditames e procedimentos, com os intentos da ação jesuítica. Em segundo lugar, tal autonomia local para a atuação dos padres concorda com o sentido da ação dos membros da Igreja, requerido por teólogos desde o século anterior. Francisco de Vitória, em sua primeira Relectio, de 1536, sobre os índios recém-descobertos, afirma que o "negócio 
dos bárbaros", retomando o evangelho de Mateus, ${ }^{11}$ não é por si evidentemente justo ou injusto. E essa elucidação, afirma o teólogo, "não compete aos jurisconsultos ou, pelo menos, não somente a eles", pois, como os bárbaros não estavam submetidos àquelas condições por direito humano, "suas coisas não devem ser examinadas pelas leis humanas, mas pelas divinas, cujos juristas não estão suficientemente capacitados para poderem, por si próprios, elucidar questões desse gênero". Uma vez que a guerra justa e a conversão e/ou cativeiro dos bárbaros são demandas de foro da consciência, "compete aos sacerdotes elucidar [o tema], isto é, à Igreja". ${ }^{12}$

Como premissa para o tratamento das matérias relativas aos índios, Vitória afirma que somente os membros da Igreja podem (e devem) deliberar sobre os procedimentos de sua conversão ou, se for o caso, da justiça da guerra travada contra eles. Para a América sob o domínio português, a recomendação aparenta ter sido semelhante. O pe. Manuel da Nóbrega, que frequentou a Universidade de Salamanca como aluno no mesmo período em que Vitória atuava como professor, entra para a Companhia de Jesus em 1544 e, poucos anos mais tarde, é enviado por d. João III ao Estado do Brasil. ${ }^{13}$ De sua chegada à recém-fundada cidade de São Salvador em 1549, junto a outros Padres da Ordem, até sua morte em 1570, aos 53 anos, Nóbrega enfrenta inúmeras dificuldades em seu projeto de ensino e catequese dos índios. Ocupa o cargo de primeiro Provincial do Brasil em 1553, Superior do colégio de São Vicente em 1567, faz parte de expedições para redução e resgate de índios etc. Nesse intervalo de três décadas, o jesuíta pratica, avalia e aprimora alguns modelos de ação e conduta dos missionários no sentido da eficácia da conversão.

Com o Concílio de Trento, a Companhia de Jesus passa a adotar os procedimentos adequados às doutrinas do catolicismo contrarreformado, pelos quais se intentava responder aos hereges do período que rompiam com sua unidade, como Maquiavel e Lutero, com suas 96 teses que sustentaram a reforma protestante. Uma dessas teses é central nas direções tomadas pela ação jesuítica: na IV sessão do Concílio, em 8 de abril de 1546, teólogos e juristas declaram anátema a tese da sola fide et sola scriptura, pela

\footnotetext{
11. A prefiguração bíblica abre o texto da primeira Relectio, pois é premissa da ação espanhola com os povos descobertos no Novo Mundo: "Ensinai a todos os povos, batizando-os em nome do Pai, do Filho e do Espírito Santo” (Mt, 28:19). Cf. vitóRIA, Francisco de. Relectiones: sobre os índios e sobre o poder civil. Organização e apresentação de José Carlos Brandi Aleixo. Brasília: Ed. UnB, 2016, p. 100.

12. VITÓRIA, Francisco de. Op. cit., p. 105.

13. HANSEN, João Adolfo. Manuel da Nóbrega. Recife: Fundação Joaquim Nabuco, Ed. Massangana, 2010, p. 18.
} 
qual Lutero afirma que o fiel pode dispensar a mediação do clero e dos ritos, devendo ter contato solitário com a escritura sagrada para fazer contato com Deus. ${ }^{14}$ Como resposta, o Concílio determina que há somente duas fontes para a Revelação, sendo os teólogos autorizados pela Igreja os únicos a terem acesso a elas, pela luz da Graça e pela instrução, e assim a possibilidade de sua transmissão oral. A primeira delas é a chamada tradição (traditio), o conjunto de textos dos diversos gêneros gregos, romanos, da filosofia, da oratória e da retórica, mas também os ritos, as cerimônias, o magistério etc. A outra se refere à leitura e interpretação dos livros sagrados, o Velho e o Novo Testamentos. ${ }^{15}$ Logo, a Companhia de Jesus, seguindo as prescrições do Concílio, adota os procedimentos a serem reafirmados pelos inacianos onde quer que estivessem atuando, reiterando constantemente o monopólio da Igreja de Roma do sentido profético da História, prefigurada nas Escrituras e confirmada pelos Doutores canônicos.

Observa-se, então, que a grande premissa teológica normativa desse mundo católico é a presença de Deus no mundo. Essa presença se dá por analogia de atribuição e proporção, hierarquicamente dividida entre os seres criados, seus conceitos e signos; e por semelhança, em que tudo é efeito da mesma Causa, mais ou menos distante, sempre subordinada ao Princípio criador, a Causa Primeira e Final que orienta as ações e o sentido do tempo. ${ }^{16}$ Deus está em tudo e em todos, como Causa e/ou como Fim. Os padres autorizados pela Igreja, como os membros da Companhia de Jesus, seriam os mais bem-dispostos a reconhecer e apontar essa presença de Deus no mundo.

Esse é o sentido da ação não somente de Vieira, na década de 1650, mas de Manuel da Nóbrega, um século antes. De sua chegada, em 1549, até meados da década

14. No decreto sobre a edição Vulgata da Bíblia, os teólogos e juristas do Concílio declaram: "Além disso, para refrear certos talentos petulantes, estabelece que ninguém, confiando no próprio juízo, ouse interpretar a Sagrada Escritura, nas matérias de fé e de moral que pertencem ao edifício da doutrina cristã, distorcendo a Sagrada Escritura segundo seu próprio modo de pensar contrário ao sentido que a santa mãe Igreja, à qual compete julgar do verdadeiro sentido e da interpretação das sagradas Escrituras, sustentou e sustenta; ou ainda, contra o consenso unânime dos Padres, mesmo que tais interpretações não devam vir a ser jamais publicadas". Cf. DENZINGer, H.; HüNERManN, P. Compêndio dos símbolos, definições e declarações de fé e moral da Igreja católica. Traduzido, com base na $40^{\mathrm{a}}$ edição alemã (2005) aos cuidados de Peter Hünermann, por José Marino Luz e Johan Konings. Versão bilingue. São Paulo: Loyola, 2006, n. 1507-1508, p. 397.

15. HANSEN, João Adolfo. Op. cit., p. 72.

16. Idem, p. 87 . 
de 1550, o vigor e o comprazimento presentes no início de sua correspondência com padres da Ordem dão lugar ao desalento diante das dificuldades não apenas da conversão, mas também da manutenção da fé nos gentios. Alguns modelos de arregimentação dos índios foram experimentados, como a presença do missionário nas tribos nômades, ou a ação de trazer índios para uma vida próxima das vilas, porém todos se mostram ineficazes. As queixas recaem sobretudo na inconstância do gentio diante dos procedimentos da conversão, ou ainda nos conflitos constantes com os europeus. Até que, em um modelo implementado em 1553 em São Vicente, Nóbrega e José de Anchieta encontram um modus operandi muito mais eficaz e com resultados muito mais consistentes, que ficou conhecido como dos aldeamentos chefiados por missionários. De fundo, altera-se a postura diante dos índios: o amor pelo qual, supostamente, aqueles homens seriam trazidos à fé dá lugar ao temor como ferramenta de sujeição política do gentio. ${ }^{17}$ $\mathrm{Na}$ prática, ajuntam-se os índios em povoações próximas às vilas, porém separadas e chefiadas por um ou dois padres. Isolados, seriam submetidos aos procedimentos que garantiriam sua conversão, a saber, a disciplina do trabalho manual, a divisão espacial dos locais por funções (casa, igreja, roça, praça etc.), a família mononuclear, castigos, além do rígido seguimento dos rituais da liturgia católica, que garantia a manutenção dos sacramentos realizados pelos missionários.

Já em 1556 esse paradigma de sujeição das gentilidades está difundido pela costa do Estado do Brasil e não cessa por ali. ${ }^{18}$ É modelo da prática jesuítica quando a ordem passa a substituir os dominicanos nas regiões da América espanhola no século seguinte, sendo amplamente difundido e adotado nas missões do Paraguai com os índios Guaranis, até a expulsão da Companhia de Jesus em meados do século XviII. ${ }^{19}$ No

17. PÉCORA, Alcir. Máquina de gêneros. São Paulo: Edusp, 2001, p. 94.

18. Ver EISENBERG, José. As missóes jesuíticas e o pensamento político moderno: encontros culturais, aventuras teóricas. Belo Horizonte: Ed. UFMG, 2000.

19. Podemos observar a relação entre os procedimentos adotados pelos missionários e a constituição do espaço de conversão dos aldeamentos em textos de jesuítas que passaram por anos de chefia e tutela de índios, nesse modelo de Manuel da Nóbrega, como o pe. Antônio Sepp, que publica em uma de suas obras o relato da vida nos aldeamentos entre finais do século XVII e início do XVIII, ou ainda no texto do pe. José Manuel Peramás, que compara a vida em um aldeamento, chamado reducción na ação com os índios guaranis, com o modelo platônico de República ideal. O risco decorrente do senso comum ao observar as ruínas desse período, na região sul da América, por estar imerso em uma narrativa de origem nacionalista e positivista, é recair sobre a hipótese ingênua da existência de um modelo de sociedade justa 
Diálogo sobre a conversão do gentio, escrito por Nóbrega entre 1556 e 1557, vemos o jesuíta articular os saberes que direcionavam as mudanças para esse novo paradigma. ${ }^{20} \mathrm{Em}$ um momento de aparente desânimo dos padres sobre as possibilidades de conversão, o texto de Nóbrega vem, por meio do diálogo, alterar o princípio da "pedagogia do amor" do programa catequético, sendo substituído pela "pedagogia do medo" ajustada aos castigos impostos nos aldeamentos e nas medidas repressivas de Mem de Sá, recém-nomeado governador-geral do Estado do Brasil. ${ }^{21}$ Vemos, a partir de então, o modelo de conversão que oferece uma política de aliança entre os propósitos espirituais da Companhia de Jesus e os planos da Coroa portuguesa para seus territórios além-mar. ${ }^{22}$ Esta ganha súditos, amplia as fronteiras e controla o território politicamente; aquela traz as gentilidades para a fé católica e se faz cada vez mais presente nos limites dos domínios dos Estados europeus, sem se subordinar aos poderes locais que não lhes convêm, ampliando e difundindo os poderes da Igreja.

Em carta datada de 8 de maio de 1558, endereçada ao pe. Miguel Torres, em Lisboa, Nóbrega oferece as razões e delibera sobre a viabilidade dessa nova fase da presença jesuítica na América portuguesa, em acerto com os poderes temporais do Reino. Texto que ficou conhecido como "Plano civilizador", a missiva coloca os elementos e resultados práticos das mudanças pensadas e já efetuadas no trabalho missionário em São Vicente. Em total congruência com a Escolástica do século xvi, de base tomista, chega a afirmar que aqueles índios que se recusarem a abandonar seus antigos rituais e modos de vida podem ser feitos cativos, por motivos de guerra justa. Incluindo-se aí aqueles que mataram e comeram, em ritual antropofágico, o bispo Sardinha, poucos anos antes.

e equitativa dentro desses aldeamentos, por supostamente estarem sendo conduzidos por padres em um socialismo avant la lettre. O que se verifica, quando se faz uma leitura focada das plantas existentes dessas edificações, é um complexo espacial que garantia os procedimentos da conversão dos índios por meio da sujeição destes aos rituais da Igreja católica e à vida prática da disciplina e da divisão hierárquica típicas de uma sociedade europeia. Ver: ZERón, Carlos. "Mission et espace missionnaire. Les bases matérielles de la conversion". Archives de Sciences Sociales des Religions, n. 169, janvier-mars 2015, p. 307-34.

20. Eisenberg afirma que o Diálogo sobre a conversão do gentio segue a tradição dos debates espanhóis sobre a conquista do Novo Mundo. O texto de Nóbrega estaria no mesmo contexto dos escritos de teólogos como Bartolomé de las Casas, na tentativa de promover a continuidade das missões religiosas na América. Cf. eisenberg, José. As missões jesuíticas e o pensamento político moderno, cit., p. 93.

21. HANSEN, João Adolfo. Op. cit., pp. 126-7.

22. PÉCORA, Alcir. Op. cit., p. 110. 
Este gentio é de qualidade que não se quer por bem, senão por temor e sujeição, como se tem experimentado; e por isso se $\mathrm{S}$. A. os quer ver todos convertidos mande-os sujeitar e deve fazer estender os cristãos pola terra adentro e repartir-lhes o serviço dos Índios àqueles que os ajudares a conquistar e senhorear, como se faz em outras partes de terras novas, e não sei como se sofre a geração portuguesa, que antre todas as nações é a mais temida e obedecida, estar por toda esta costa sofrendo e quase sujeitando-se ao mais vil e triste gentio do mundo. ${ }^{23}$

Impossível entender os princípios que dão sentido às práticas do pe. Antônio Vieira, um século depois, sem compreendermos como esse contexto de atuação de Nóbrega, e daquela geração de jesuítas, lidou com os saberes da teologia católica e com a prática da conversão experimentada em diferentes situações, nas primeiras décadas da presença portuguesa na América. A relação é sabida, pois as doutrinas da chamada Segunda Escolástica, do século XVI, são evidentes nos rumos da ação política traçada por ambos os padres, cada qual em um momento da história política da colonização portuguesa. A posição de Vieira no Maranhão e Grão-Pará está consistentemente vinculada às experiências de Nóbrega, não apenas pelas situações correlatas em que se colocavam nas fronteiras do poder da Coroa, em contato constante com a barbárie dos sertões, para fora dos arredores da cidade, mas também pelas mediações estabelecidas com os diversos poderes pelos quais deveriam articular politicamente sua ação, nas hierarquias do Reino, com os Gerais da Companhia, nas lideranças locais das tribos etc. Essa articulação, imprescindível à atividade missionária, vinha por vezes como um obstáculo a ser vencido, por exemplo, na tarefa da arregimentação e conversão dos índios, além da viabilidade dos empreendimentos, como requerer meios para a construção de um colégio ou garantias de não intromissão do governo local, dadas pelo rei. Mas, ao mesmo tempo, também poderia sinalizar enquanto componente aliado no projeto de sujeição dos grupos indígenas, como o governo de Mem de Sá, representando novo fôlego para a atividade jesuítica no século xvi, ou o de André Vidal de Negreiros, partidário de Vieira na garantia da aplicação das leis de defesa contra a escravidão dos gentios no Maranhão.

23. LEITE, Serafim S.I. Cartas dos primeiros jesuítas do Brasil. Vol. II (1553-1558). São Paulo: Comissão do IV Centenário da cidade de São Paulo, 1957, pp. 448-9. 
Quando lemos o Diálogo sobre a conversão do gentio de Nóbrega, ou os textos proféticos de Vieira, como a História do futuro, vemos que as articulações aparentes nas cartas escritas tanto por um quanto por outro instrumentalizam projetos que estão ordenados pelos mesmos princípios teológicos que orientam o tempo, a política e a história. Obedientes às doutrinas da Igreja católica e, acima de tudo, fiéis ao ethos beligerante da Companhia de Jesus, os padres estão engajados na defesa do bem comum, fim último do pacto de sujeição que garante a soberania da Coroa, o que pressupõe a concórdia e a paz entre as ordens sociais do corpo político-místico do Império Português. Recorrendo aos saberes da Escolástica, matéria do ensino e da doutrina dos padres nas universidades europeias e nos colégios da Companhia, Nóbrega e Vieira pensam o ordenamento político a partir da hierarquia das leis sistematizada por Tomás de Aquino na Suma Teológica. ${ }^{24} \mathrm{Na}$ questão 91 da Suma, sobre a diversidade das leis, Aquino afirma que as leis humanas, positivas, concernentes aos poderes temporais, são deliberadas entre os homens segundo disposições particulares para cumprir fins contingentes, sem negar ou contrariar os princípios da lei natural. ${ }^{25}$ Esta reflete a Lei Divina e está presente no coração dos homens pela sindérese, a luz da Graça inata que direciona, por normativa, os princípios virtuosos que estão na alma, como fazer o bem e evitar o mal. Ao questionar, mais à frente, se a lei natural é um hábito, Tomás de Aquino alega que ela estaria acima deste, pois é a participação da Lei Eterna na criatura racional. Mas, quando aparece nos atos dos homens, a lei natural se dá por meio dos hábitos, uma vez que estes são o modo de se fazer o que ela recomenda e direciona, na prática repetitiva, aperfeiçoando as ações que a refletem. ${ }^{26} \mathrm{Ou}$ seja, o livre-arbítrio é necessário para que, com o uso da razão, os homens escolham aperfeiçoar suas ações, por meio dos hábitos, segundo a lei natural. Daí podemos inferir que as leis humanas, quando propõem dar conta das contingências locais, devem oferecer e garantir o espaço de ação dos homens no sentido do aperfeiçoamento da lei natural, a partir dos hábitos virtuosos que a confirmam como orientadora da vida coletiva em uma comunidade política.

O corpo político, subordinando as diferentes ordens sociais ao bem comum, é então ordenado pelo pacto de sujeição que se fundamenta no consentimento das partes

24. Suma Teológica, $\mathrm{I}^{\mathrm{a}}-\mathrm{II}^{\mathrm{a}}$, questões 90-97. Cf. AQuino, Tomás de. Suma Teológica. São Paulo: Loyola, 2005, pp. 521-603.

25. Suma Teológica, $\mathrm{I}^{\mathrm{a}}-\mathrm{II}^{\mathrm{a}}$, q. 91, art. 3 .

26. Idem, q. 94, art. 1. 
pela cabeça, o rei, conquanto ela siga, nas leis e normativas positivas, os ditames da lei natural, garantindo os hábitos virtuosos nas ações dos homens seus súditos. Tais hábitos, poderíamos afirmar, seriam o controle dos apetites individuais, a amizade e a concórdia entre as partes e a aplicação da justiça terrena, mantendo cada qual em seu lugar, com sua função. Esses princípios são norteadores das ações dos padres inacianos como Nóbrega e Vieira, pois ambos, enquanto letrados e versados nas doutrinas da Igreja da Contrarreforma - que, por sua vez, é síntese dos saberes da teologia cristã -, têm claramente para si a legibilidade do ordenamento que sustenta e caracteriza a posição dos reis católicos e de toda a estrutura político-teológica que configura a República como corpo de base mística. Em Vieira há, ainda, a especificidade em dispor da sistematização apresentada por Francisco Suárez nas obras De legibus, de 1612, e Defensio fidei, de 1613. Nesta última, em resposta às doutrinas defendidas pelo rei Jaime I de Inglaterra sobre o direito divino dos reis, Suárez vai afirmar que o verdadeiro domínio não é resultado da escolha direta de Deus daquele que deva ser o soberano, mas que o governo político advém da escolha dos súditos em se sujeitar ao príncipe cristão que vá conduzi-los em direção à justiça e à paz da vida beata. Esse discernimento dos homens, defendido pelo teólogo, difere da tese luterana da lei do pecado original, pela qual os homens seriam seres decaídos, incapazes de entender os preceitos da lei natural. Ao contrário, mesmo manchados pelo pecado, os fiéis sempre buscam o bem. É nessa particularidade que reside a liberdade cristã.

Contudo, por um lado, a liberdade cristã não consiste na isenção face a leis humanas justas nem na imunidade perante a justa coação ou punições de pecados cometidos contra a paz e a justiça, mas consiste ao invés na isenção face à lei mosaica ou ao temor servil, ou (o que é o mesmo) consiste na livre submissão por amor e caridade, a qual não só não repugna ao regime humano, como ainda o reforça sempre que está presente - e se na verdade não estiver presente, suprime a sua ausência através da coação. ${ }^{27}$

No combate ao absolutismo inglês de base luterana, Suárez vai aproximar ainda mais as noções de Direito positivo e Direito Natural, ao afirmar que, ao se reunir em socieda-

27. suÁrez, Francisco. Defensio fidei, III, IV, 18 (grifos meus). Ver: suárez, Francisco. "Defesa da Fé Católica e Apostólica contra os erros da Seita Anglicana". In: Escola ibérica da paz nas universidades de Coimbra e Évora. Portugal: Almedina, 2015, p. 281. 
de, o homem está submetido à intervenção divina unicamente como causa eficiente, ou causa prima et universalis, sempre requerida no estabelecimento de uma comunidade política. ${ }^{28}$ Essa causa é o que direciona a livre decisão dos súditos pois é preciso supor um ato moral na origem da vida coletiva, como uma forma de contrato. Sua unidade vem da reunião das partes desse contrato em busca de um fim que, para Suárez, é político. A cabeça, ou o príncipe católico, é o "organismo diretor" ${ }^{29}$ que garante as condições para o conjunto da sociedade atingir esse fim, o bem comum. Jean-François Courtine demonstra que a tarefa do soberano, nesse contexto, é garantir uma unidade do corpo em direção a esse fim próprio da vida terrena, pois através das leis humanas os homens podem atingir a felicidade coletivamente. Ou seja, para além dos teólogos que pensam as doutrinas sobre as constituições políticas, a partir do novo paradigma após a descoberta do Novo Mundo, Suárez trata do bem comum como concernente ao Direito positivo, alcançável na vida dos homens em comunidade, mesmo que manchados pelo pecado original.

Digamos, esse avanço na sistematização das doutrinas da teologia de base tomista é perceptível na obra do pe. Antônio Vieira, não apenas nos textos proféticos ou nos sermões, mas também nas cartas, pelas quais instrumentaliza os poderes ao seu redor em nome desse fim terreno. Vieira sabe e defende que os proveitos da Igreja de Roma - representada pela Companhia de Jesus - e da Coroa portuguesa, com a adequada conversão dos índios no Maranhão, são os mesmos. Sendo Portugal o reino destinado a espalhar a fé católica pelo mundo, converter o gentio em nome do rei é sujeitar aqueles homens ao corpo político-místico do Império. Se, na oratória ou no gênero histórico, Vieira pode colocar diante dos olhos do leitor/ouvinte as aproximações que edificam esse fim último de seus atos e deliberam pela sua viabilidade, no gênero epistolar a conversa se dá pelas vantagens e desvantagens, terrenas e transcendentes, em se adotarem medidas, leis e garantias do adequado tratamento dos assuntos da conversão. A matéria principal, reiteradamente colocada desde as primeiras cartas do Maranhão, em 1653, é assim a necessidade de autonomia de ação dos jesuítas nesses assuntos, e principalmente dele, Vieira, na região. O objetivo principal, com isso, é claro: evitar a escravização injusta dos índios por parte dos residentes, em uma extensão do domínio luso onde a presença da mão de obra africana é rara e cara.

28. COURTine, Jean-François. Nature et empire de la loi. Études Suaréziennes. France: Éditions de l'École de Hautes Études en Sciences Sociales, 1999, p. 151.

29. Idem, p. 152. 
A retórica epistolar, nesse sentido, é também síntese de saberes seculares ordenados, como síntese ou acúmulo, no intento da máxima eficácia persuasiva do texto que circulava entre seus interessados. Assim, por meio da divisão estabelecida na dispositio da carta - que remonta aos manuais da ars dictaminis do século XII -, a petitio, a petição, é o centro pelo qual se compõe a retórica epistolar. É para tornar justas, viáveis e convenientes as solicitações e demandas nos assuntos da missão que Vieira compõe sua narratio, articulando a benevolência do destinatário, seu leitor, à narração sobre o estado das coisas nos aldeamentos, nas vilas, nas entradas etc. Ao mesmo tempo, segue os preceitos ditados pela Companhia de Jesus, que tem nas cartas dos padres aos irmãos em Cristo e superiores um método de compartilhamento das experiências, dificuldades e felicidades locais. É sabido o papel decisivo do pe. Juan Afonso de Polanco, secretário de Inácio de Loyola, na elaboração das diretivas de 1547, ou as determinações sobre cartas nas Constituições da Companhia, publicadas em 1556, prescrevendo a rotina e a composição das epístolas a serem enviadas periodicamente pelos inacianos espalhados pelo mundo.$^{30}$ Assim, Vieira pressupõe, na elaboração do texto das missivas, a regra primeira do decoro na retórica epistolar, estabelecendo o lugar do destinatário em relação a si, se tido por superior, como reis, rainhas, príncipes, superior da Ordem, membros da primeira nobreza das cortes europeias; igual, em mesma posição, como os outros padres nas missões; ou inferiores, no caso, o chefe índio Lopo de Sousa, chamado Principal Guaquaíba, em carta de 22 de janeiro de 1661. Essa equidade da presença do remetente, no estilo, em relação ao destinatário, ${ }^{31}$ cabe não somente porque obedece, formalmente, às regras sociais em vigor, mas também porque guarda os princípios de eficácia persuasiva do texto epistolar.

Por meio das tópicas convenientes ao gênero, as cartas cumprem o propósito da conversa entre ausentes. Presentes já no epistolário ciceroniano, esses procedimentos figuram-na como testemunho da amizade entre as partes, como recurso contra a ausência, e ainda como expressão da distância que impede uma conversa mais franca. Aristotelicamente, Vieira articula os diversos caracteres de pessoa que compõem o ethos do emissor, associa-os às paixões que movem o destinatário em direção a uma opinião conveniente à causa, e insere as proposições baseadas nas dez categorias da

30. HANSEN, João Adolfo. "Para ler as cartas do pe. Antônio Vieira (1626-1697)". Teresa: Revista de Literatura Brasileira, São Paulo, n. 8/9, 2008, p. 291.

31. Idem, p. 281. 
lógica, como elencadas por Pierre de la Ramée, ${ }^{32}$ para assim alcançar a eficácia persuasiva necessária, de acordo com a posição (social e de mando) do leitor, seu correspondente. $\mathrm{O}$ método, inserido na instituição retórica, está presente no grande número de obras, de vasta circulação a partir do século XVI, sobre a arte de escrever cartas. ${ }^{33} \mathrm{O}$ objetivo, para Vieira, é contingente. Em cada momento de uma vida de atuação nos assuntos da política, da história e da conversão, o jesuíta intermediou as estratégias de presença local, entre sermões, profecias, pareceres, votos e petições, com um vasto conjunto de cartas, negociais ou familiares, instrumentalizando aquilo que, por vezes, aparecia como matéria edificante nos púlpitos ou prenúncios de um futuro próximo. Para assegurar tal procedimento, faz uso dos preceitos da retórica epistolar, encenando sua presença em uma conversa com um destinatário que não se fazia presente, mas que poderia viabilizar seu projeto, ali, nos assuntos da missão. É nesse sentido que devemos observar a capacidade engenhosa do jesuíta nos atos de escrita de sua correspondência: a capacidade de alcançar o decoro conveniente na encenação da presença do remetente com o destinatário.

Azevedo afirma que nos primeiros meses, após a chegada de Vieira ao Maranhão, em janeiro de 1653 , houve por parte dos jesuítas da missão uma tentativa de apaziguamento dos ânimos, em nome de uma convivência pacífica dos padres com os moradores locais, evitando tocar nas questões sobre a escravização dos índios. ${ }^{34}$ Porém, não parecia haver meio-termo. Existia, de um lado, um consenso sobre a impossibilidade da vida sem escravos, sendo a presença indígena fator de abundância de mão de obra para os portugueses instalados na região, e, de outro, os padres certos da necessidade da salvação das almas daquela gentilidade, que não poderia ser feita cativa injustamente. Desse contexto, observamos, já em maio daquele mesmo ano, uma extensa carta de Vieira endereçada ao pe. Francisco Gonçalves, Provincial do Brasil, em que narra o início da murmuração sobre a atuação dos jesuítas contra o cativeiro dos índios, a partir da pregação do sermão das Tentações, ou "Sermão da primeira dominga da Quaresma”. Nele, Vieira condena a política de escravização dos índios presente

32. LA RAmée, Pierre de. Dialectique. Paris: Chez André Wechel, 1555.

33. Podemos citar, por exemplo, a sistematização realizada pelo conde Emanuele Tesauro, em 1678. Ver: TESAURO, Emanuele. Arte de cartas missivas, o methodo general para reducir al papel quantas materias pide el politico comercio. Trad. espanhol D. Marcelo Migliavada. Espanha, Valencia: Jayme de Bordazar, 1696. 34. AZEvedo, João Lúcio de. História de Antônio Vieira, cit., tomo I, p. 215. 
nas "razias", as entradas no sertão apoiadas pela administração local, para a feitura e comércio de escravos.

Preguei na seguinte dominga, que era a das Tentações, e tomando por fundamento o Haec omnia tibi dabo, ${ }^{35}$ que era a terceira, mostrei primeiramente, com a maior eficácia que pude, como uma alma vale mais que todos os reinos do mundo; e depois de bem assentado este ponto, passei a desenganar com a maior clareza os homens do Maranhão, mostrando-lhes com a mesma que todos estavam geralmente em estado de condenação pelos cativeiros injustos dos índios; e que, enquanto este habitual pecado se não remediasse, todas as almas dos portugueses deste Estado iam e haviam de ir para o Inferno. Propus finalmente o remédio, que veio a ser em substância as mesmas resoluções da nossa resposta, mais declaradas e mais persuadidas, facilitando a execução e encarecendo a conveniência delas; e acabei prometendo grandes bênçãos de Deus e felicidades, ainda temporais, aos que por serviço do mesmo Senhor, e por salvar a alma, lhe sacrificassem esses interesses. ${ }^{36}$

Segue, na mesma carta, uma longa descrição do quão eficaz foi a pregação, sentida no coração dos homens da região que, "sem haver palavra de contradição nem discórdia", logo foram "executando o exame das liberdades na conformidade que se assentou, e são já muitos os índios que estão livres, e não só índios senão nações inteiras, sem haver quem o contradiga nem se queixe, que é coisa que faz admiração." Reconhecendo a carência sentida pela população de mão de obra para os serviços da região, Vieira é enfático quanto à "eficácia da Divina Graça, que contra a opinião de todos e da sua própria os reduziu e rendeu; sinal, sem dúvida, de que tem Deus entre eles muitos escolhidos". ${ }^{37}$

Retoricamente, seria eficaz relatar ao Superior da Ordem grandes e rápidos efeitos da ação dos missionários recém-chegados naquelas partes. Não parece, pelas cartas que se seguem, que os moradores locais foram, assim como narra Vieira, arrebatados de pronto pelas palavras de força do padre pregando na Quaresma. No ano seguinte, Vieira escreve ao rei d. João IV sobre as dificuldades encontradas na salvação das almas, todas causadas por governantes locais, ao tratarem a terra "como donos e não como rendeiros", perturbando o trabalho nas Missões e "impedindo o remédio e salvação

\footnotetext{
35. Mt 4:9.

36. vieira, Pe. Antônio. Op. cit., carta 67, pp. 104-5.

37. Idem, p. 106.
} 
das almas". ${ }^{8}$ Diferentemente do que escreveu o jesuíta na carta ao Provincial, no ano anterior, os governantes locais insistem em agir pela vantagem pessoal, sem obedecer às ordens do rei e, consequentemente, dificultando o trabalho de conversão. A solução, aponta o jesuíta, é isentar os padres de obedecer aos mandos da governança local.

E porque a distância do lugar não sofre dilações, nem interlocutórios, Vossa Majestade se sirva de mandar tomar no particular de nossas Missões uma resolução última, com a qual nos livre por uma vez de requerimentos e demandas com ministros de Vossa Majestade, porque se não estivermos isentos deles, nunca poderemos conseguir o fim para que viemos, da conversão e salvação das almas, e será o melhor retirarmo-nos a tratar só da quietação das nossas. ${ }^{39}$

Nos dias que se seguem a esta, de 4 abril de 1654, Vieira persiste em escrever a d. João IV sobre as dificuldades encontradas com os moradores locais. Datava do ano precedente o parecer do rei, revogando as leis anteriores à chegada dos inacianos e adotando medidas que garantiam aos padres a tutela dos índios, o que gerara diversos conflitos e desobediências. ${ }^{40}$ Vieira narra todas elas ao soberano de Portugal, cita os crimes cometidos pelo governador Gaspar Cardoso, com anuência do vigário-geral do Pará, Mateus de Sousa, ao desobedecer às ordens de Sua Majestade, fraudando papéis que, supostamente, tolhiam a ação dos padres, tudo narrado na missiva endereçada ao monarca. ${ }^{41}$ Toda a denúncia vem para, por fim, compor a petição: "que mande Vossa Majestade acudir aos ministros do

38. Idem, carta 71, pp. 159-60.

39. Ibidem.

40. AZEvedo, João Lúcio de. Op. cit., tomo i, p. 226.

41. Na mais recente edição das cartas de Vieira, foram restabelecidos os possíveis nomes citados pelo padre, que haviam sido censurados em edições anteriores, publicadas desde o século xviII. Em carta de 15 de abril, Vieira tenta persuadir o Procurador da Província do Brasil que restrinja a circulação da carta anterior, ao Rei, na qual citava os nomes dos mandatários locais que descumpriam as leis reais. Os cuidados do jesuíta nas cartas parecem evidenciar uma situação delicada com os poderes locais: "Assim que peço muito a Vossa Reverência, por amor de Nosso Senhor, que se estes negócios se pudessem concluir sem estes papéis saírem a público, de maneira que se consiga o remédio das almas sem ofensa alguma do próximo, e se Sua Majestade quisesse resolver isto em algum conselho particular e secreto, ou por si mesmo (que é o melhor de tudo), a maior mercê que Sua Majestade me podia fazer, e a maior que Vossa Reverência que todas as vezes que me vejo metido nestes labirintos e escrúpulos, no mesmo lugar em que vim buscar a quietação, que assim chego a duvidar dela, e não sei que há de ser de mim”. vieira, Pe. Antônio. Op. cit., carta 76, p. 184. 
Evangelho; que mande libertar a pregação da fé, e desforçá-la das violências que padece; que mande franquear o caminho da conversão das almas, e pô-las no alvedrio natural em que Deus as criou".42 As ordens do rei, diz o padre, são pouco temidas e seguidas naquelas partes, pela distância e isolamento em que se encontram. ${ }^{43}$ Por essa razão é que reitera, na conclusão, a necessidade da intervenção real nas questões do índio:

Assim, senhor, não há senão isentar Vossa Majestade as Missões de toda a intervenção e jurisdição dos que usam tão mal da que têm e da que não têm, e libertar Vossa Majestade os missionários da pregação do Evangelho, pois Deus a fez tão absoluta e tão livre que não é bem que até a salvação dos índios seja neste Estado cativa como eles. ${ }^{44}$

Compreende-se a força da denúncia narrada na missiva como uma reação do jesuíta às ações da administração local das vilas do Maranhão e do Grão-Pará. Naquele mesmo período, a Câmara de São Luís enviava procuradores à Corte portuguesa, na busca pela revogação da lei que Vieira tinha conseguido fazer vigorar com a intervenção do rei proibindo o cativeiro dos índios. Observa-se uma tentativa de acordo entre as partes, mas a nova fórmula resultante da interpelação parecia, aos olhos do padre, não mais frear as investidas daqueles que intentavam a escravidão indígena. ${ }^{45} \mathrm{~A}$ imputação enérgica dos crimes contra o bem comum e do não cumprimento das diretivas reais de outubro de 1653 serve, retoricamente, ao intento de comprovar a ineficácia de qualquer possibilidade de acordo com os governos locais. É nesse mesmo sentido que nos instantes seguintes Vieira redige outra missiva ao rei, mas agora elencando as dezenove medidas a serem adotadas pela Coroa, pelas quais se assegurava a salvação das almas dos povos gentios, depositando todos os passos da conversão, administração e controle dos aldeamentos nas mãos dos missionários. ${ }^{46}$ Dentre as regras, estava determinado que todo e qualquer trabalho realizado por um gentio aldeado para um morador ou obra pública deveria ser pago, e adiantado. Além disso, as entradas no sertão passariam a ser

\footnotetext{
42. Idem, carta 72, p. 167.

43. "[...] porque o recurso está mui distante, e não há navio senão de ano em ano, e em um ano, e em um mês, e em um dia perdem-se, senhor, muitas almas." Idem, p. 167.

44. Ibidem.

45. AZEvedo, João Lúcio de. Op. cit., tomo I, pp. 248-9.

46. vieira, Pe. Antônio. Op. cit., carta 74, pp. 172-8.
}

Teresa revista de Literatura Brasileira [19]; São Paulo, 2018 • 283 
feitas somente por "pessoas eclesiásticas", e se achados os chamados "índios de corda" designação daqueles capturados por tribos inimigas -, esses deveriam ser examinados pelos religiosos sobre sua condição de cativo. Não satisfeito, Vieira decide se deslocar até Lisboa para, junto ao rei, tentar tornar leis tais medidas.

Sua partida para visitar a Corte se dá em meio a hostilidades, surgidas da murmuração que se alastra da notícia de sua viagem, meses antes. ${ }^{47}$ Já em Lisboa, em novembro de 1654, encontra d. João IV doente, o que talvez possa ter contribuído para um estado de desânimo, antevendo aquilo que ocorrerá pouco tempo depois, a saber, a morte do rei e o fim do apoio que garantia a postura aguerrida do jesuíta. Possivelmente o ethos enérgico com que prega, para a Corte, o sermão de Santo Antônio, em 13 de junho de 1655, seja uma reação pragmática de Vieira diante do risco de um prognóstico nada alentador para as suas próximas ações. De qualquer modo, retorna ao Maranhão, nesse momento, como Superior das Missões. Além de ter conseguido fazer vigorarem as medidas elaboradas na carta de abril de 1654, pode agora assumir a direção dos aldeamentos, distribuir os missionários que iriam administrá-los, além de poder contar com o governo local de André Vidal de Negreiros para a garantia do cumprimento das leis. Assim como o governo temporal de Mem de Sá representou novo fôlego na ação catequética de Nóbrega e seus irmãos, Vidal de Negreiros parece trazer novo ânimo para o projeto de Vieira, em sua volta da Corte. Em carta ao Provincial, de $1^{\circ}$ de junho de 1656 , Vieira faz-se presente em papel ${ }^{48}$ para solicitar um "superior de virtude, letras, experiência e exemplo" que possa visitar a Missão e tomar notícia dela, além de "um grande número de bons sujeitos, que venham assistir com estes índios". ${ }^{49}$ Segue, daí, descrevendo as razões da utilidade da presença da Companhia de Jesus na região. Dentre as seis que enumera, diz que "os ministérios em que trabalham os que estão no Maranhão são os próprios e particulares da Companhia", diferentemente do Estado do Brasil, onde são comuns às outras Ordens. Declara também que, ao contrário da "Província do Brasil", “a Missão do Maranhão está em seus princípios e, no fervor de suas perseguições, exposta aos olhos de todos, e muito mais arriscada a perder o crédito”. Afirma:

47. AZEvedo, João Lúcio de. Op. cit., tomo I, p. 254.

48. "E assim é força dizer a Vossa Reverência por escrito alguma parte do que havia de representar em presença, sentido de que haja de ser o intérprete de nossas necessidades, e solicitador de seu remédio, um papel, que, sobre dizer pouco, não sabe responder ao que lhe perguntam, nem satisfazer ao que lhe replicam." vieira, Pe. Antônio. Op. cit., carta 84, p. 215.

49. Idem, p. 216. 
Se olharmos para a glória ainda humana e honra da mesma Província, não há dúvida que muito maior lha granjearão, para com Deus e para com os homens, os sujeitos que mandar ao Maranhão, que muitos dos que sustenta e ocupa no Brasil; porque o ler um curso, ou fazer quatro sermões, não é o que nos honra, singulariza, ilustra, senão as conquistas da fé, e as almas convertidas a Deus, que é a matéria que há tanto tempo tem faltado à nossa Província $[\ldots] .5^{50}$

Desde sua volta ao Maranhão e Grão-Pará, em inícios de 1656, até o final da década, a ação de Vieira é marcada, por um lado, pela conquista do protagonismo da Ordem nas coisas da conversão, na região, e, por outro, pela reação crescente dos poderes locais contra a presença dos jesuítas, que estariam, em tese, agindo contra o bem comum da República, ao dificultar a vida dos moradores que precisavam da mão de obra cativa. $\mathrm{O}$ poder que intermediava a tensão surgida do conflito, tendendo para as requisições dos inacianos, era o rei e, da parte de Vieira mais especificamente, o assentimento próximo do Bispo eleito do Japão, o pe. André Fernandes, confessor de d. João IV. A principal riqueza da região eram os escravos, feitos, dizia-se, por guerra justa. Descidos do sertão às centenas, grande parte seria libertada pelos padres em seus exames. ${ }^{51}$ Somente eles poderiam saber, pela doutrina, da justiça da guerra. Pelo que se observa na correspondência de Vieira, a presença jesuítica naquelas partes não pôs fim ao cativeiro indígena, único fator de geração de riqueza almejado pela governança local. Conseguiam, durante esse período, alcançar certo equilíbrio entre a produção e venda de mão de obra e conversão e sujeição de vassalos ao reino.

Entretanto, em 6 de novembro de 1656, morre d. João IV. O jesuíta perde seu principal apoio, por onde podia fazer valerem suas demandas, mesmo que conflitasse diretamente com o governo local. De 1657 em diante, até sua expulsão de Belém, em 1661, Vieira vai aos poucos vendo-se vencido em seu projeto de conversão dos povos bárbaros do sertão. Fica evidente em suas cartas desse período como vai perdendo cada vez mais o controle das ações na região, ao mesmo tempo que o novo governante, na Corte, já não correspondia ao apoio que lhe fora dado outrora pelo rei falecido. A própria Companhia de Jesus passa a ser alvo de investidas do Conselho de Estado, por conta de assuntos relativos à presença judia no reino, o que de certa forma enfraquece

50. Idem, p. 219.

51. AZevedo, João Lúcio de. Op. cit., tomo I, pp. 296-7. 
também os poderes da Ordem..$^{22}$ Vieira, por seu turno, deposita suas esperanças no futuro, elaborando as teses do Quinto Império do Mundo, em que o próprio d. João IV viria a ressuscitar e cumprir o destino de Portugal, como reino escolhido por Deus para difundir a fé.

$\mathrm{Na}$ carta que envia à rainha regente d. Luísa, em $1^{\circ}$ de setembro de 1658 , vemos os rumos tomados por Vieira nas petições que faz ao poder real. Aqui, como nas enviadas ao príncipe d. Afonso VI, feito rei anos mais tarde, os pedidos de garantias e vigência das medidas protetoras das ações dos jesuítas nas missões dão lugar ao ethos arrefecido da misericórdia pelas almas dos índios e das súplicas pela manutenção das conquistas já alcançadas na ação dos padres missionários. Sabendo que não poderia contar com uma pronta disposição do rei, como ocorria com d. João IV, Vieira constitui a si mesmo, para a rainha, como devoto isento de qualquer interesse pessoal. Diz que os favores que solicita são somente em nome do interesse da manutenção das missões: "porque naquele sacrifício renunciei tudo; nem o mundo tem que me dar, depois que me deu quanto tinha, e quanto podia, e eu o pus nas mãos de Deus para o empregar melhor".53 Não vemos mais Vieira pleitear novas medidas de interesse para os missionários do Maranhão, mas apenas que o novo governante cuidasse para que nada daquilo já alcançado fosse perdido.

O que só peço em nome de todos os religiosos destas Missões é que Vossa Majestade nos mande conservar sempre na firmeza das ordens que trouxe o Governador de que acerca das Missões e dos índios se não mude nem altere coisa alguma; mandando Vossa Majestade recomendar de novo ao Governador a assistência em favor dos missionários, em forma que entenda ele, e todo o Estado, que o maior cuidado e desejo de Vossa Majestade é o aumento e propagação da fé e conversão das gentilidades, como verdadeiramente é, e que os religiosos da Companhia, como ministros da conversão, hão de ter sempre na grandeza e justiça de Vossa Majestade muito segura a proteção e amparo.54

Em inícios de 1661, Vieira sabe da notícia da morte de seu último grande apoiador, o pe. André Fernandes, o que representa, por fim, a derrocada do projeto missionário do jesuíta. O governador d. Pedro de Melo já não garantia o cumprimento das leis como

\footnotetext{
52. Idem, p. 300.

53. Vieira, Pe. Antônio. Op. cit., carta 89, p. 244.

54. Ibidem.
} 
André Vidal de Negreiros fizera anos antes. O príncipe e a rainha regente não asseguravam a presença da Companhia, e os moradores, munidos do apoio das Câmaras locais, constantemente levantavam motins pela expulsão dos padres da região. Foi o que ocorreu naquele mesmo ano, como narra Azevedo.

Faz-se imprescindível analisar esse período de atuação do padre Antônio Vieira, como missionário, a partir das forças conflitantes, em seus intentos, com a teologia-política vigente. Vieira se dá por vencido, não sem antes fazer uso de todos os recursos disponíveis, na defesa daquilo que acreditava ser politicamente virtuoso na ação do reino católico diante dos povos bárbaros do sertão. Porém, a sucessão de eventos o leva gradativamente - é o que aparentam as cartas - a fazer concessões de todos os lados possíveis para, em nome do grande projeto, não perder o controle da missão como um todo. É assim, talvez, que podemos observar a condescendência com que se faz entender vez ou outra sobre a escravidão de certos grupos indígenas, ou uma aparente contradição na relação com o escravo africano. As sucessivas mortes, primeiramente do príncipe herdeiro do trono português, d. Teodósio de Bragança, em 1653, seguida do rei d. João IV e, por fim, do pe. André Fernandes, colocam Vieira em uma situação delicada na qual não havia mais em quem se apoiar, nos poderes terrenos, para sustentar seus propósitos divinos para com a conversão. As cartas, se analisadas em conjunto, evidenciam esse percurso. Nos períodos posteriores haverá outras sequências de episódios que o levarão, no final da vida, a se isolar na Quinta do Tanque, na Bahia, cuidando dos escritos da Chave dos profetas. Os poderes atuantes no jogo entre as potências europeias, no século XVII, e as questões que interessavam a cada um desses poderes impedem o padre de exercer seu papel como jesuíta, na acepção da moral católica que acreditava justa.

No entanto, a ação de Vieira não pode ser observada como resultado de uma militância pessoal e particular em nome da fé. Talvez possa, em sua instrumentalidade nas ações terrenas e práticas que delibera convenientes, mas não nas razões que dão sentido ao seu fim último. Nos seus escritos, Vieira, Nóbrega, assim como Vitória e Suárez, revelam uma uniformidade de preceitos, sustentados doutrinariamente, que incidem justamente na proeminência dos teólogos em ordenar os assuntos da política católica nos séculos XVI e XVII, uma vez que seu fim temporal é indissociável dos fins últimos da sua Causa Primeira, em sentido oposto ao de Maquiavel. É o que determina a conveniência de Vieira em requisitar, reiteradamente, a autonomia de ação dos inacianos nos assuntos da conversão.

Esses preceitos estão erigidos sobre três conceitos, que fazem dos teólogos os únicos capazes de decidir quais são os melhores caminhos da política temporal das 
Coroas submetidas à Igreja de Roma: a Verdade, o Bem e a Justiça. São eles os conceitos pelos quais aquele sistema metafísico de semelhanças aproxima as coisas, como dito por Foucault. O primeiro, talvez o mais importante dos três, é o que está presente como prefiguração da História, no Velho e no Novo Testamento. O tempo católico, no século XVII, não é cíclico, mas possui um fim e caminha em sentido determinado, submetido aos desígnios de Deus em direção ao Juízo Final. Esse sentido está presente, enquanto figura, nos acontecimentos bíblicos, que não são representação, mas as próprias coisas figuradas dos eventos futuros. ${ }^{55} \mathrm{~A}$ Verdade dos atos e episódios da História estava nos escritos sagrados interpretados pelos Padres da Igreja, como Santo Agostinho e Tomás de Aquino. Basta possuir as ferramentas para identificá-los. Nessa capacidade é sustentado o que a Contrarreforma doutrinou contra a tese luterana, determinando que só os padres autorizados poderiam ler e interpretar o texto bíblico. São eles que têm a perspicácia de encontrar a Verdade das coisas. E é por meio dessa Verdade, decifrável para Vieira, que lemos um texto como a História do futuro, pois, para o jesuíta teólogo, os eventos que fariam parte da história de Portugal já estariam figurados e dispostos nos escritos sagrados. Igualmente ocorre quando Vitória cita as passagens bíblicas para provar que os bárbaros, em contato com os espanhóis, não possuem leis humanas válidas se estas impedirem o direito natural ou divino. ${ }^{56}$ Enquanto teólogo autorizado, ele pode identificar e julgar a questão, pois conhece a Verdade, que dá sentido à História.

O segundo conceito, o de Bem, é aquele pelo qual os homens, em suas ações, agem iluminados pela sindérese. A luz da Graça inata, presente no coração dos homens, reflete a lei de Deus e é por isso que o missionário tem o dever de levar a Palavra aos bárbaros e trazê-los para a fé de Cristo. Essa capacidade do homem de tomar certas decisões é, para Tomás de Aquino, uma potência tornada hábito. ${ }^{57}$ São os teólogos, no caso, os que possuem os instrumentos intelectivos - devido à doutrina e ao letramento - para decifrar tais hábitos e identificar o bem nas ações das pessoas. Mais uma vez, é Vieira que aponta para as características que fazem de índios, mesmo os das tribos mais hostis, como os Nheengaíbas, homens dispostos e voltados a se sujeitar à fé e ao corpo político da Coroa, pois enxerga, neles, ações voltadas para o bem.

55. Ver Auerbach, Erich. Figura. São Paulo: Ática, 1997; Hansen, João Adolfo. Alegoria. Construção e interpretação da metáfora. São Paulo: Hedra, 2006.

56. vitória, Francisco de. Op. cit., p. 145.

57. Suma Teológica, $\mathrm{I}^{\mathrm{a}}$, q. 79, artigo 12.

288 MUNHÓS, Fernando. As cartas do padre Antônio Vieira no Maranhão 
A Justiça, por seu turno, como terceiro conceito, é ato moral que, individualmente, pode ser atingido por meio das faculdades que constituem a pessoa - vontade, memória e inteligência -, orientadas as três pela prudência, chamada escolasticamente recta ratio agibilium, a reta razão das coisas do agir. ${ }^{58}$ É fazendo uso dela que os homens podem discernir, na contingência, a verdade e o bem manifestados pela sindérese. Tomás de Aquino, quando descreve a lei natural, afirma que alguns têm a razão depravada pela paixão, pelo mau costume ou pela má disposição da natureza, mas é verdadeiro que se aja segundo ela. ${ }^{59}$ Os teólogos são os representantes da doutrina da fé que sabem, na prática, agir pela prudência e, assim, alcançar a equidade da justiça terrena, reflexo da divina, por meio da razão. Ao mesmo tempo, orientados pela recta ratio factibilium, ${ }^{60}$ a reta razão das coisas do fazer, os teólogos, prudentes, dominam os preceitos da linguagem que determinam os modos engenhosos e verossímeis de comunicar, pelos atos da escrita, a justiça das ações locais e dos deveres diante dos desafios, como o da conversão. A razão especulativa é, nesse sentido, a ação prudente que ordena as coisas para a consideração da verdade. ${ }^{61}$ No discurso, para a retórica judicial e deliberativa, pode-se encenar o domínio, por parte do emissor, das proposições lógicas aplicadas à causa, ou o manejo espontâneo das leis positivas que regem a justiça local.

$\mathrm{Na}$ última carta que escreve ao príncipe d. Afonso, em maio de 1661, às vésperas de deixar definitivamente o ofício de missionário no Maranhão, Vieira relata a emboscada feita pelos moradores aos padres, fato que acarretou sua expulsão. Como um contrapeso à murmuração criada pelo governador sobre os motivos de tal ocorrência, o jesuíta oferece as verdadeiras razões que levaram os inacianos a conflitar com os moradores até o ponto da ocorrência dos motins. Vieira afirma não terem sido as razões verdadeiras aquelas elencadas por d. Pedro de Melo, ou seja, a prisão do índio Lopo de Sousa Guarapaúba, ou a publicação na região de cartas escritas por Vieira, respectivamente, ao Príncipe e ao bispo do Japão, com a relação do que se tinha obrado nos últimos tempos e das "contradições que tinha neste Estado a propagação da fé". Afirma

58. HAnsen, João Adolfo. “Para ler as cartas do Pe. Antônio Vieira (1626-1697)”, cit., p. 283. Suma Teológica, $\mathrm{I}^{\mathrm{a}}-\mathrm{II}^{\mathrm{a}}, \mathrm{q} \cdot 57$.

59. Suma Teológica, $\mathrm{I}^{\mathrm{a}}-\mathrm{II}^{\mathrm{a}}$, q. 94, artigo 4.

6o. HANSEn, João Adolfo. Op. cit., p. 283.

61. Tomás de Aquino, I ${ }^{\mathrm{a}}$, q. 79, artigo 11. 
justificadas as causas, mas somente como a última ocasião. As verdadeiras razões, afirma, residem na "cobiça insaciável dos maiores", agindo contra as leis do rei, tanto no Maranhão quanto no Pará.

Assim que, senhor, por guardarmos as leis de Vossa Majestade, e porque damos conta a Vossa Majestade dos excessos com que são desprezadas, e porque defendemos a liberdade e justiça dos miseráveis índios cristãos, e que de presente se vão convertendo, e sobretudo porque somos estorvo aos infinitos pecados de injustiça que neste Estado se cometiam, somos afrontados, presos e lançados fora dele. ${ }^{62}$

São os jesuítas, pois, teólogos autorizados, nas palavras de Vitória, que sabem julgar e deliberar sobre as questões que se referem à relação entre a presença da fé nas regiões dos domínios da Coroa e a efetivação dos poderes reais representados nas ordens e estamentos que compõem o corpo político. Arrogam-se a esse papel pois veem a si mesmos como aqueles membros da Igreja e súditos do rei católico que sabem apontar a Verdade na história e no tempo, o Bem na prática dos homens e a Justiça na política dos governos temporais. Isso se dá porque, doutrinariamente, dominam um conjunto de saberes que decifram pragmaticamente o sentido pelo qual Deus, como Causa primeira, direciona os homens, na vida em sociedade. É doutrina uma vez que tal protagonismo é resultado de instrução e de letramento recebido nas universidades europeias ou nos colégios da Companhia, que reúne e instrumentaliza politicamente os saberes sobre a teologia, além daqueles sobre o bem dizer, da retórica e da oratória. Assim, Vieira sabe quais as melhores decisões a serem tomadas sobre os índios em sua relação com os moradores da região. Sabe quando deve fazer concessões ou quando precisa representar uma rigidez mais enérgica. $\mathrm{Ou}$, ao menos, acreditava saber.

Sua prática, porém, foi vencida pelas forças que iam contra os caminhos da fé e da difusão da Palavra. Sua estratégia, que contava com os poderes centrais do Estado, fora derrotada e não viu outro caminho senão deixar a atividade de missionário. Tudo isso é evidente na correspondência desse período. Ali, estão articulados os saberes que circulam enquanto preceitos e doutrinas, cumprindo objetivos específicos da retórica epistolar, pela qual aquela estratégia estava sendo viabilizada. As conexões entre a circularidade de doutrinas e preceitos que constituem a postura do jesuíta, representada

62. Vieira, Pe. Antônio. Op. cit., carta 111, p. 325. 
em seus textos, e os saberes que trazem eficácia para a retórica em suas cartas podem oferecer uma perspectiva sobre o tema muito menos ingênua para a análise histórica do que os que buscam contradições do padre quanto às questões da escravidão.

Fernando Munhós é doutorando em Literatura Brasileira na Faculdade de Filosofia, Letras e Ciências Humanas da Universidade de São Paulo. 